\title{
Guiding principles for sustainability
}

\author{
Momentan gibt es zwar nur wenige aber ernstzunehmende Hinweise auf schäd- \\ liche Folgen von Nano-Partikeln. Es ist davon auszugehen, dass zukünftige Ent- \\ wicklungen in der Nanotechnologie nicht nur ökologische Entlastungen, sondern \\ auch neve Risiken für Mensch und Umwelt mit sich bringen werden. Der Einsatz \\ von nachhaltigen Leitbildern im Entwicklungsprozess könnte dazu beitragen, \\ negative Folgen zu vermeiden.
}

A Rüdiger Haum und Ulrich Petschow Rüdiger Haum und Ulrich Petschow entific circles debate the potential of nanotechnology to contribute to a better world. The more the protagonists of these debates emphasise how strongly nanotechnology will change the world, the more obvious it becomes that change will not come without unwanted side effects.

Currently, a small scientific discourse on negative effects associated with nanotechnology and its applications is emerging. Scientists already have indicators for possible hazards concerning the environment and human health stemming from nanoparticles. Nano-particles are particles of any substance of a size smaller then $100 \mathrm{~nm}(0.1 \mu \mathrm{m})$. Nano-particles are about to be produced commercially in significant volumes and are already used in a number of commercial products.

\section{Effects on humans?}

Nano-particles are extremely mobile and may, once introduced, translocate within the body to liver, brain and even the foetus. Research carried out in England strongly suggests that nano-particles travel through openings in the cell membrane generally used for the transport of macromolecules as far as to the fetus within animals. Research in the United States tracked the dispersion of different nano-particles (Carbon particles $35 \mathrm{~nm}, 30 \mathrm{~nm}$ Mn-Oxide, $50 \mathrm{~nm}$ Colloid-Gold) after they were applied to nasal mucosa of rats and primates. They were in all cases detected in the olfactory bulb after deposition and concentrations rose until the experiments had ended. Nevertheless, little is known about what effect nanoparticles will have when they reach the brain. There are also indications that carbon matter causes inflammatory reactions within rats. Nanoparticles inhaled by rats could be found in their livers six hours thereafter. Current research also suggests that nanotubes may damage the lungs when inhaled. The related studies are, however, contradictory in their results. Some researchers point furthermore out that nanotubes might provoke cancer due to their size and stability. After all, there are contradicting research results whether the inhalation of nano-scale titanium dioxide causes damage to the lung (1).

\section{- Environmental effects?}

Research on possible environmental effects of nano-particles is still in its infancy. There are some worries about the ability of nanoparticles and microparticles to change heavy metal and radionuclide mobility in the environment. Also, the behaviour of nano-particles (agglomeration, dispersion, etc.) in the environment is unclear. It is also suspected that certain types of nano-particles might enter the food chain. The preliminary findings of research carried out in the United States are

- States of aggregation of nanoparticles may change in various aqueous environments

- Adsorption of contaminants to the surfaces of nanoparticles is very strong

- Adsorption/desorption of organic compounds to nanoparticles may be hysteretic

- Adsorption/desorption of heavy metals onto/ from nanoparticles are likely, based on a normalised surface area sorption isotherm

- Nanomaterials in natural aqueous environments may substantially affect the fate and transport of contaminants.

It has also been demonstrated in US-research that fullerenes have a toxic effect on largemouth bass, daphnia and E. Coli bacteria. It has to be underlined that the current knowledge about possible negative effects of nano-particles on human health is contradictory, inconclusive and therefore preliminary. There is not likely to be one simple answer when it comes to whether or not nanoparticles are 'safe'. Differences in size, shape, surface area, chemical composition and bio persistence require that the possible environmental and health impact be assessed for each type of nanomaterial in its own right: closely similar compounds may induce substantially different effects. The mentioned findings do not only demonstrate the need for further scientific enquiry into the respective areas but also the need for the careful and attentive development of future nanotechnological applications. Measures of technology shaping should be taken to avoid harmful effects of future innovations already during the development process. The potential to control the development of a technology is limited. Also, single actors are not capable to fully shape technology according to their intentions - however powerful they might be. Successful realisation of an innovation involves a highly complex network of participants (actors), the so-called innovation system. Guiding principles play a prominent role within innovation processes. Therefore the question opens up, in how far guiding principles could be used to actively influence innovation processes.

\section{Guiding principles as instruments}

Guiding principles have a coordinating and synchronizing function within complex innovation systems or technology emergence networks. Guiding principles reduce complexity, focus perception, motivate and, quite often, also lend legitimacy. We know that guiding principles work by motivating and by constituting a group identity, as it is currently the case within the NanoTechnoScience-community. If guiding principles are to be effective, among their most important requirements are graphic quality and emotional content, in short, their capacity to resonate with the consciousness of the actors concerned (2).

Three elements are of central importance: their pictorial quality, their guiding function, and that they are grounded within the realms of the feasible. Pictorial quality is very important in ensuring orientation, lucidity, and reduction of complexity. The guiding function relies on emotional and value content, providing motivation and orientation. And they need to be in touch with reality and should therefore not be too abstract in nature. „Sustainable economic development“, for instance, appears to be too complex, too abstract and too defensive a notion to serve as a useful guiding principle. For the short term, we might start by proposing a guiding principle termed resource-efficient nanotechnology. For the medi- 


\begin{tabular}{|c|c|c|c|}
\hline Guiding principle & Theme/Maxim & Focus & Examples \\
\hline \multirow{2}{*}{$\begin{array}{l}\text { Resource-efficient } \\
\text { nanotechnology }\end{array}$} & As little harm and resource & \multirow{2}{*}{$\begin{array}{l}\text { The quantity of energy and } \\
\text { material flows (life cycle-oriented) } \\
\text { in relation to the benefits to society }\end{array}$} & \multirow{2}{*}{$\begin{array}{l}\text { Low-wear and low-abrasion } \\
\text { surfaces (mechanical engineering) } \\
\text { Highly specific membranes } \\
\text { (biotechnology, fuel cells) }\end{array}$} \\
\hline & consumption as possible & & \\
\hline Consistent and & Adapted to reflect the & The quality and quantity of & Nanotubes \\
\hline inherently safe & metabolic principles and & material and energy flows, & Spiders' silk \\
\hline \multirow[t]{4}{*}{ nanotechnology } & capacities of nature as a & and technical risks in respect & in lightweight structures \\
\hline & whole and of human beings & to health and environment & biodegradable or recyclable \\
\hline & (minimal depth of intervention & & \\
\hline & and high fault tolerance) & & \\
\hline \multirow[t]{4}{*}{ Nanobionics } & "Learning from nature", & The quality of technology & (Bio)Catalytic converters / \\
\hline & life-supporting, cooperating & (the form of interaction & enzyme technology \\
\hline & $\begin{array}{l}\text { with the principles of self- } \\
\text { organization within our own }\end{array}$ & with nature) & Bio mimetic materials synthesis \\
\hline & bodies and nature as a whole & & \\
\hline
\end{tabular}

Source: von Gleich

um term the principle of consistent and inherently safe nanotechnology would be adopted and, in the long term, nanobionics. These guiding principles should be mutually integrative in that the longer-term principles always incorporate the goals of the shorter-term ones. Elements of some guiding principles for sustainable nanotechnology are given in table 1 .

The construction of technical systems on the basis of the (guiding) principle of inherent safety has a fairly long-standing tradition in fields such as nuclear technology and chemical process technology. Here, however, comparatively specific emergency and malfunction scenarios form the underlying basis, with the systems built to counteract and contain the predicted dangers. Nevertheless pursuing ,inherently safe nanotechnology“ or even ,,sustainable nanotechnology" will of course not lead to a totally risk-free and inherently safe technology.

Knowledge about the possible impact of technologies (technology assessment) or substances (toxicology, ecotoxicology, industrial health and safety) will always essentially remain insufficient and incomplete. Both ,worst-case scenarios“ and ,guiding principles" can offer guidance and suggest boundaries within which the process of exploration and innovation should operate, i.e. assist in averting what we categorically wish to prevent, and may bring us closer to our goal of inherently safe - or even sustainable - nanotechnology.

Elements of inherently safe nanotechnology might include the use of ,inherently safe substances" within the boundaries of an, inherently safe technology" which in turn lies within the framework of ,inherently safe application systems“. The uncontrolled dispersion of nanoparticles can pro- bably be prevented by applying the following principles in shaping technology and choosing between alternatives:

i) rapid loss of potentially harmful ,nanoproperties" if emitted into the environment (e.g. through agglomeration),

ii) rapid breakdown of used substances (biological and photochemical degradability),

iii) low bioavailability and bioaccumulation of substances and particles,

iv) restriction to „,contained applications“ (avoidance of open applications, very good containment).

\section{Towards sustainable nanotechnology}

In choosing sustainable nanotechnology as a guiding principle, a technology-oriented approach was adopted, taking technology as a starting point. We could, instead, have opted for one of two alternative or competing concepts: the ,problemoriented“ or „need-oriented“ approaches. The problem-oriented approach centres on climate protection, resource conservation or risk minimization; here, nanotechnology would form part of the picture only where it was expected to help solve the problem. The same is true for the needoriented approach, for which guiding principles such as ,sustainable building and habitation" would be the starting point. To reiterate: ,sustainable nanotechnology" is, therefore, a technology-oriented guiding principle. Given that the development dynamics in nanotechnology are, in many sectors, still largely technology-driven, focusing on technology-oriented guiding principles appears to be a promising idea. Broadening the approach to respond to specific human needs should present no problem if the focus is on specific areas of use, i.e. sustainable ,application“ or sustainable ,utilization“ of nanotechnology, as for example in ,ultra-light construction of (recyclable) vehicles on the basis of nanotube-reinforced materials" (3).

These guiding principles are in part 'extracted' from the actual debate about the potentials of nantechnology. On the other hand they are systematised constructions. They cannot (yet?) be fully articulated and presented within these pages. It is, in any case, rather improbable that any such proclamations from ivory towers (academic or otherwise) will be successful. If we are to test a guiding principle for its resonance, this will require debate - although such discourse should in no way be restricted to collect already existing views, emotions and positions. Guiding principles must be far more than merely the lowest common denominator; they cannot simply be linked to the present collective awareness. Guiding principles need a generous helping of irritation and provocation - for it is these stimuli that often generate the best response.

\section{References}

(1) Haum, R. et al.: Nanotechnology within the Framework of the Precautionary Principle. Schriftenreihe des $10 \mathrm{~W}$ 173/04, Berlin 2004.

(2) Gleich, A. v.: Leitbildorientierte Technikgestaltung - Nanotechnologie zwischen Vision und Wirklichkeit. In: Böschen, S.; Schneider, M.; Lerf, A. (Hrsg.): Handeln trotz Nichtwissen. Campus-Verlag, Frankfurt/Main; New York (im Erscheinen)

(3) Gleich, A. v.: Potential ecological and health effects of nanotechnology; Approaches to prospective technology assessment and design. In: Steinfeldt, M. (Ed.): Nanotechnology and Sustainability. Prospective Assessment of a Future Key Technology. Schriftenreihe des IÖW 167/03, Berlin 2003.

\section{Die Autoren}

Dr. Arnim von Gleich ist Professor für Technikge staltung und Technologieentwicklung an der Universität Bremen. Rüdiger Haum ist wissenschaftlicher Mitarbeiter im, Ulrich Petschow Leiter des Forschungsfeldes Umweltökonomie und -politik am Institut für ökologische Wirtschaftsforschung (IÖW). Kontakt: Universität Bremen, Badgasteiner Str. I, 28359 Bremen. Tel. 0421-2182844

E-Mail: gleich@uni-bremen.de, IÖW, Potsdamerstr. 105, 10785 Berlin. Tel. 030-8845840.

E-Mail: ruediger.haum@ioew.de 
(c) 20I0 Authors; licensee IÖW and oekom verlag. This is an article distributed under the terms of the Creative Commons Attribution Non-Commercial No Derivates License (http://creativecommons.org/licenses/by-nc-nd/3.o/), which permits unrestricted use, distribution, and reproduction in any medium, provided the original work is properly cited. 